\title{
The View from Kosovo: Challenges to Peace-building and State-building
}

\author{
Ilir Deda *
}

Kosovo in its third year of independence faces three sets of challenges: internal, regional, and international. The consolidation of the state is affected by developments in these three areas, and the degree of success in these realms will directly affect the future and the substance of the new state. The international community, once focused on building peace and stability in Kosovo (from 1999-2008) has recently shifted its focus toward the functionality of the new state's institutions and the rule of law. Kosovar society, on the other hand, is focused on an internal debate about what kind of a state it wants.

\section{Internal Challenges}

The lack of consensus in the international community about Kosovo's independence has led to the proliferation of international missions in Kosovo. Apart from the United Nations mission in Kosovo (UNMIK) and the NATO-led Kosovo Force (KFOR), there is the International Civilian Office (ICO), the European Union's Special Representative (EUSR), the European Union's rule of law mission (EULEX), the European Commission's Liaison Office (ECLO), the Organization for Security and Cooperation in Europe (OSCE) mission in Kosovo, the EU's special representative for the North, and the EU's special coordinator on religious heritage. On top of these, there is the "Quint" - the embassies of the United States, United Kingdom, France, Germany, and Italy — which play a very important role in Kosovo's political development. The ICO is the only mission that is not status-neutral, and oversees the implementation of the Comprehensive Status Proposal (CSP) of Marti Ahtisaari. All other missions are status-neutral - i.e., they express neither support for nor opposition to the independence of Kosovo. The overall coordination of the entire international presence is still taking time.

EULEX is the European Union's most serious undertaking in Kosovo to date. It includes approximately fourteen hundred police officers, fifty judges and prosecutors, and roughly twenty customs officers. The mission has a mandate to monitor, mentor, and advise Kosovo's institutions involved with creating and maintaining the rule of law; in addition, it has executive authority to combat organized crime, corruption, financial and economic crime, as well as war crimes and inter-ethnic crimes. However, the current staffing level does not allow the mission to focus much on the improvement of the performance of Kosovo's legal institutions, especially the judiciary. Of the fifty EULEX judges and prosecutors, 75 percent are focused on issues within the reserved authority of the mission, while the rest work on its monitoring, mentoring, and advisory

Ilir Deda is the Executive Director, Kosovar Institute for Policy Research and Development (KIPRED). 
mandate. Also, the disproportion between the number of EULEX police officers and the customs officers, judges, and prosecutors is intentionally high, in order to allow the mission to substantially improve Kosovo's weakest legal link: its judicial and prosecutorial functions. Also, due to the divisions in the EU regarding Kosovo's independence (twenty-two EU member states have recognized Kosovo, while five have not), there is no clear policy guidance from Brussels, and the mission does not have executive authority in northern Kosovo. Instead, the actions of the mission in the North are held hostage by Belgrade's policies, and are developed in a dialogue between Brussels and Serbia.

Kosovo's internal developments following its declaration of independence have gone through three short phases: the honeymoon in 2008; disillusion in 2009; and the battle for internal democracy, development, and accountable institutions in early 2010. Kosovo's society is consumed with finding the answer to the question of what kind of state Kosovo should be. The problem with the political elite in Kosovo is that it has misunderstood Kosovo's form of governance in two key respects. First, it held to the belief that as long as the government delivers on the international community's demands, various internal aspects of Kosovo's governance would not be examined, and questions would not be asked. Second, Kosovo's elite understood that the improper management of public finances would not be penalized as long as the core demands of the international community were met. The prevalent opinion in the government has been to implement the Ahtisaari plan and maintain the overall level of political and security stability in the country, including improving relations with the Kosovo Serb community.

However, the lack of economic development coupled with widespread corruption within the public sector has caused disillusionment among the population. In January 2010, government support stood at 36 percent. International donors, who were mostly interested in investing during 2008, were discouraged by the corrupt tendencies within the government. Negative trends were noted in the areas of freedom of speech and the rise of corruption. The Kosovo government has tightened its grip over the public broadcast networks and independent media.

Since Kosovo's declaration of independence, the dominance of the government over the economy has dramatically increased, as has its interference in the appointment of senior public servants. Public investment increased by 194 percent, while private investment declined by 10 percent. At the same time, the amount of single-source tendering rose to 164 million Euros in 2009, from 50 million Euros in previous years. This has led to an unfriendly business environment, further damaged by the practice of individuals and groups close to senior governmental officials establishing ad hoc companies that then apply for and win tenders for public contracts. This has only added to suspicions of enormous government corruption.

The autocratic tendencies of the government have met with growing criticism from the few remaining independent media outlets and several non-governmental organizations. Civil society is endeavoring to find its role in the state, and continues to uphold and fight for democratic standards and principles. As a result of having been deprived of internal democratization for so long, in 2010 Kosovar society may perhaps be one of 
the most dynamic societies in the world. The nation is undergoing a transformation of the kind that other states in the region experienced during the late 1990s and early 2000s.

Inter-ethnic relations were the main focus of the attention of the international presence until the end of 2009. In reality, in the wake of independence Kosovo Albanians did not see the Kosovo Serbs as a Serbian fifth column used to destabilize and threaten the country. The Serbs immediately saw an increase in their safety, security, and freedom of movement, which has done a great deal to ease relations between the two communities, except in northern Kosovo. The Kosovo Serbs south of the Ibarra River began a process of accommodation within the new reality. They participated in Kosovo's local elections of 15 November 2009, and directly became stakeholders in the process of decentralization and creation of new municipalities. In Gracanica and Strpce, in central and southern Kosovo (two of the largest Kosovo Serb settlements, after northern Mitrovica), Kosovo Serb participation in the local elections was higher than in the elections organized by Serbia in May 2008 and August 2009.

The new municipalities have legitimate leadership, and the process of transferring authority to them has begun, albeit slowly. The Kosovo Serbs understand that, in order to have a predictable future and any chance at sustainable development, cooperation with the institutions of the new Kosovo state is crucial. The accommodation of Serbs within Kosovo's institutions will prove to be a significant opportunity for the two communities to solve issues of concern within a single institutional and legal framework.

The new municipal leadership in Kosovo Serb areas faces pressure from their community to deliver rapidly on the promises made to improve standards of living. The existence of parallel structures maintained by Serbia represents another factor that may hinder the functionality of the new municipalities. While the parallel structures deliver only financial benefits to the Serbs, they cannot offer development. High salaries in the parallel municipalities cannot match the opportunities offered in Kosovo towns. Meanwhile, Serbia has committed 42 million Euros for parallel structures, and is not showing any sign that it will change its policy regarding the participation of the Serbian community in Kosovo's political institutions. Moreover, Serbia's path towards EU membership is wide open, without any specific conditions attached regarding a change of policy towards the northern region of Kosovo.

There is a widespread belief that the northern, Serb-controlled municipalities of Leposavic, Zvecan, and Zubin Potok are not cooperating with the new state institutions. However, in the budget plan for 2010, the Kosovo government has allocated a regular amount of 8 million Euros for the functioning of these municipalities. In December 2009, the International Civilian Office (ICO) and the Government of Kosovo presented a strategy for the integration of northern Kosovo. On 24 February 2010, the government appointed Ylber Hysa, former member of Parliament and former adviser to the mayor of Mitrovica, to serve as the coordinator for the implementation of the strategy for northern Kosovo. The biggest problem with the strategy lies in the EU's lack of official support for its implementation, and the lack of effective operations on the part of EULEX to provide the necessary level of rule of law in the area. Instead, the 
EU has appointed a special envoy for the North, and has opened an "EU House" in northern Mitrovica.

The strategy for the North (or the comprehensive approach to the integration of northern Kosovo) outlines specific steps that should be taken by the international presence for restoring rule of law in the area, as well as the gradual inclusion of the Serbs in the institutions of Kosovo through the process of decentralization, free elections, and economic development. The successful implementation of the strategy would entail the neutralization of the actions and presence of Serbia's security apparatus in the area, which is composed of over 350 members of Serbia's police, intelligence service, and gendarmerie. The presence of these personnel violates the Kumanovo Agreement between NATO and the Federal Republic of Yugoslavia (FRY) of 1999, which ended NATO's air campaign against the FRY, and UN Security Council Resolution 1244. But in order to achieve the successful reintegration of the north, diplomatic pressure on Belgrade by the European Union and the United States is an essential prerequisite. To date, however, this has not been the case. Furthermore, the international community has given their silent blessing to the organization of Serbia's parallel elections in Mitrovica North, scheduled for 30 May 2010. Brussels and Washington think these elections will help Serbia's President Boris Tadic win and consolidate power and responsibility in Mitrovica North, where his opponents in Serbia-the Democratic Party of Serbia (DSS) and Serb Radial Party (SRS) - are strong.

\section{Regional Challenges}

The relationship between Serbia and Kosovo is crucial for the region's stability and progress towards European integration. Kosovo is unable to participate in various regional cooperation forums due to blockage by Serbia and Bosnia and Herzegovina (Republic of Srpska). Serbia's ultimate goal regarding Kosovo is the partition of Kosovo along the Ibarra River, and the inclusion of the northern part within Serbia's redefined borders. Belgrade believes it will have greater diplomatic leverage after the International Court of Justice (ICJ) issues its advisory opinion on the legality of Kosovo's declaration of independence later this year. Belgrade is determined to take the issue to the UN General Assembly, hoping the assembly will call for fresh status talks with Pristina. Furthermore, the pressure of the international community towards Serbia and Kosovo will grow in a quest to achieve a model of cooperation between the two countries, without requiring an explicit recognition of Kosovo by Serbia.

Belgrade has unofficially started discussing an option involving the exchange of territories between Kosovo and Serbia, in which Serbia would offer the municipality of Presevo in the Presevo Valley in exchange for northern Kosovo. There are EU member states that support the partition as a solution, continuing to uphold the policy of "Serbia first." There are other states within the EU that would compromise the territorial integrity of Kosovo, or would dismantle Ahtisaari's package in order to satisfy Serbia at the expense of Kosovo. However, the prevailing opinion within the "Quint" is against the partition of Kosovo, because this would have a regional domino effect. Hence, even if 
Serbia and Kosovo agree on partition, the international community will not allow it to proceed.

Furthermore, northern Kosovo is among the pillars of Kosovo's economic development; Lake Gazivode is the largest water reserve in the state, and is used for the development of energy, irrigation, and agriculture, and also provides drinking water for almost half a million people. In addition, much of the state's mining industry and mineral resources are located in northern Kosovo. Another factor strongly against partition is the presence of the Kosovo Serbs living south of the Ibarra River, who represent almost two-thirds of the entire Kosovo Serb population. Without the inclusion of the north in a Kosovar state, they would see fewer reasons to remain in Kosovo, and would slowly leave. Half of the Serbian Orthodox Church (SPC) is also opposed to the partition of Kosovo. Therefore, in 2011, when the talks between Belgrade and Pristina are most likely to take place, there will be an emerging reality in Kosovo of a loose crossethnic alliance both for and against partition of Kosovo.

The status of the North, however, remains unclear, even with the opposition to partition. An emerging possible solution being discussed in diplomatic circles is a status similar to that of South Tirol. This special status for North Kosovo would enhance the current rights of Kosovo Serbs in this part of the territory, with a semi-independent police service, judiciary, health care and education system, and its own finances. The institutions would be linked both to Pristina and Belgrade beyond the provisions of the CSP. However, yet another internal rearrangement in Kosovo- this one involving the granting of territorial autonomy - will most likely destabilize the country. It is unlikely that public opinion among Kosovo Albanians will accept such an outcome, after barely accepting Ahtisaari's plan. Further, it will raise suspicion regarding the ability of the international community to provide rule of law in an area of 2000 square kilometers with approximately 50,000 people, which is the territory north of the Ibarra River.

There are unfounded fears - both in the West and in the region - that Kosovo will soon join Albania. At this point, this scenario is not likely. There is no desire for unification, especially in Albania, while pro-greater-Albania parties in Kosovo currently have less than 3 percent support. This scenario may become a reality in the future if Kosovo's economic stagnation continues, and Kosovars find equal opportunities in Albania. For this scenario to succeed, the basic requirement is booming economic growth in Albania and a welcoming professional environment for Kosovars, which is not the case at present. Also, Kosovo's society is focused on strengthening its own statehood and building functional democratic institutions that would foster a friendly developmental environment.

\section{International Challenges}

In over two years of existence, Kosovo has been recognized as an independent country by only sixty-seven states. This low number creates an opinion of Kosovo as an "unfinished" story in the Balkans. There are two broad reasons why the recognition of the new state has stagnated: international relations in early 2008, and Kosovo's case at the ICJ. The most damaging factor for Kosovo's development is the opposition in the EU 
to recognizing its independence by Spain, Slovakia, Greece, Romania, and Cyprus. Until these states agree to accommodate Kosovo's reality, Pristina will not have contractual powers with Brussels, and will remain the only country in the Western Balkans without a clear path toward European integration.

It is unlikely that there will be a new massive wave of recognitions after the ICJ produces its advisory opinion. This opinion will most likely be ambiguous, and both parties - Serbia and Kosovo - will interpret it according to their own needs. Belgrade's determination to request the resumption of status talks from the UN General Assembly may further complicate the fate of the new state. Therefore, it is of crucial importance for Kosovo to coordinate its post-ICJ diplomatic actions with the states that have recognized it, especially the countries that make up the International Steering Group (ICG) - a body of twenty-seven countries that support the ICO.

However, for Pristina it is of the utmost importance to have a clear path toward integration in Europe, the same as other Western Balkans countries have. Gaining full international legitimacy will happen over time, which Kosovo can afford. In a period of five years it is likely that Kosovo will have normalized relations with Serbia, which is a condition for both countries before any further European integration can take place. By that time, it is most likely that Kosovo will have been recognized by over one hundred countries. However, at present, the new state cannot afford to have its path toward integration in Europe blocked.

\section{Conclusion}

On 28 April 2010, EULEX raided the offices of Kosovo's Ministry of Transport, Post, and Telecommunications, as well as the private houses of the minister himself. The mission announced that this was the beginning of tough measures against crime and corruption. The mission announced that actions will be taken in at least four other ministries of the government of Kosovo. Kosovo society has been waiting for such measures since the deployment of the mission. The independent media and civil society have publicly called on EULEX to use its executive authority more aggressively, and to more fully implement its mandate in fighting crime and corruption.

EULEX's actions have faced no opposition. The suspected minister has publicly pledged cooperation with the judiciary. This is the first time in eleven years that the international community has taken a direct role in combating corruption and crime in Kosovo. It marks and the beginning of the decriminalization of Kosovo's politics, and is the first step to ending a decade-long period of impunity in the new state.

If EULEX continues with its anti-corruption measures, it will open a new phase in the development of Kosovo's society, and the state overall. These measures mark the beginning of the end of the post-conflict environment, and the focus will fundamentally shift towards building democratic institutions in the state. This shows that the international community has shifted its previous focus on peace and its own interpretation of stability toward an emphasis on building a functional and democratic state with accountable institutions. Kosovo's society has received impetus in its internal democratization development, and has gained the necessary internal space to mature. 